Darrow, D. C., Pratt, E. L., Flett, J., Gamble, A. H., and Wiese, H. F. (1949). Disturbances of water and electrolytes in infantile diarrhea. Pediatrics, 3, 129.

Hirschhorn, N., Kinzie, J. L., Sachar, D. B., Northrup, R. S., Taylor, J. O., Ahmad, S. Z., and Phillips, R. A. (1968). Decrease in net stool output in cholera during intestinal perfusion with glucose-containing solutions. New England fournal of Medicine, 279, 176.

Hirschhorn, N., McCarthy, B. J., Ranney, B., Hirschhorn, M. A., Woodward, S. T., Lacapar, A., Cash, R. A., and Woodward, W. E. (1973). Ad libitum oral glucose-electrolyte therapy for acute diarrhea in Apache children. Fournal of Pediatrics, 83, 562.

Ironside, A. G. (1973). Gastroenteritis of infancy. British Medical fournal, 1, 284.

Nalin, D. R. (1975). Sucrose in oral therapy for cholera and related diarrhoeas. Lancet, 1, 1400.

Whitelaw, A. C. L., Dillon, M. J., and J. H. Tripp. (1975). Hypertension, oedema, and suppressed renin aldosterone system due to unsupervised salt administration. Archives of Disease in Childhood, 50, 400.

P. M. Rahilly, R. Shepherd, D. Challis, J. A. WALKER-SMITH, and J. MANLY

Queen Elizabeth Hospital for Children, Hackney Rd., London E2 8PS.

*Correspondence to Dr. J. A. Walker-Smith.

\section{Recurrent thrombocytopenic purpura associated with accessory spleen}

The course of most cases of childhood idiopathic thrombocytopenic purpura (ITP) is acute and self-limiting but a few patients, mostly older children, have a chronic form requiring splenec- tomy, as in adults. Macpherson and Richmond (1975) differentiated the chronic form, with its long history of episodic purpura, from the acute form, which is more common in children and has a history from onset of symptoms to diagnosis of less than 100 days. The acute form has a strong tendency to spontaneous and permanent remission. Finkelstein (1921) suggested that accessory spleens might be a cause of recurrence of ITP after splenectomy. Since then many others have commented on this association. We report a case of ITP which recurred after splenectomy. The removal of an accessory spleen produced a partial remission.

\section{Case report}

A 12-year-old boy presented in 1967 with epistaxis and conjunctival haemorrhages. He had bruised easily for 6 months before admission. He had had no significant illnesses and no family history of any bleeding disorder. A blood count showed $\mathrm{Hb} 8 \cdot 6 \mathrm{~g} / \mathrm{dl}$, platelets $<10000 / \mathrm{mm}^{3}$, WBC $5000 / \mathrm{mm}^{3}$, with a normal differential. The bone marrow showed moderate cellularity with increase in megakaryocytes but was otherwise normal. Treatment with dexamethasone $2 \mathrm{mg}$ three times a day produced no response after 3 months, and splenectomy was performed in January 1968. Splenic histology was normal. The platelet count rose to $1 \mathrm{million} / \mathrm{mm}^{3}$ by the second postoperative week (Fig. 1). After a further 6 weeks he was asymptomatic and the platelet count was $400000 / \mathrm{mm}^{3}$. He was not seen again for a year, when he presented with a history of bruising and epistaxis for 3 weeks. His platelet count was $10000 / \mathrm{mm}^{3}$. Within 2 weeks of starting a 4 -month

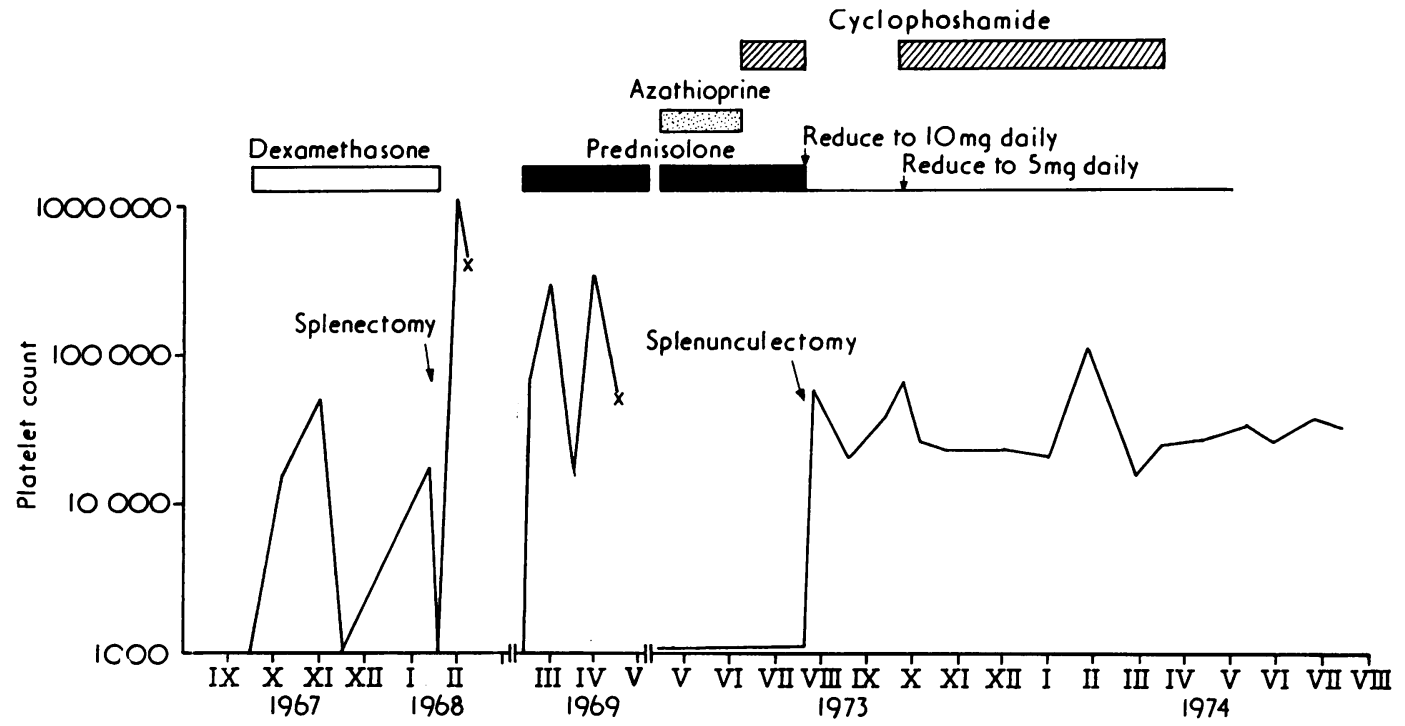

FIG. 1.-Graph of platelet counts throughout course of illness. 
course of prednisolone his platelet count rose to 250000 $/ \mathrm{mm}^{3}$. This fell to $56000 / \mathrm{mm}^{3}$ by 22 May 1969 .

The patient was not seen again until 1 May 1973, when he was readmitted with a severe epistaxis. He had been well in the 4-year interval apart from a tendency to bruising. He had purpura on his limbs and trunk, oral petechiae, and pale mucous membranes. $\mathrm{Hb}$ was $9.5 \mathrm{~g} / \mathrm{dl}$, WBC $15000 / \mathrm{mm}^{3}$ with a normal differential, platelets $5000 / \mathrm{mm}^{3}$, ESR $8 \mathrm{~mm}$ in $1 \mathrm{~h}$, no LE cells found, ANF negative, serum albumin $4.4 \mathrm{~g} /$ $100 \mathrm{ml}$, serum globulin $3.8 \mathrm{~g} / 100 \mathrm{ml}$. $X$-ray examination of the chest was normal. He was transfused with 4 units of whole blood and started on prednisolone $40 \mathrm{mg}$ daily. Platelet counts were consistently below 5000 $/ \mathrm{mm}^{3}$. Nose bleeds continued to be severe at times. Azathioprine $100 \mathrm{mg}$ /day increasing to $250 \mathrm{mg}$ /day was started on 11 May 1973. This regimen failed to produce a response after 2 months, as did infusion of 3 units of fresh frozen plasma. On 4 July 1973 the immunosuppressive therapy was changed to cyclophosphamide $100 \mathrm{mg}$ daily. This was given for 4 weeks, but his platelet count and clinical condition failed to respond. The possibility of an accessory spleen was considered. Using the method of Atkins et al. (1972), a spleen scan with ${ }^{99 m} \mathrm{Tc}$-labelled red cells showed an area of uptake in the epigastrium. A repeat spleen scan 2 weeks later by the same technique confirmed this finding (Fig. 2).

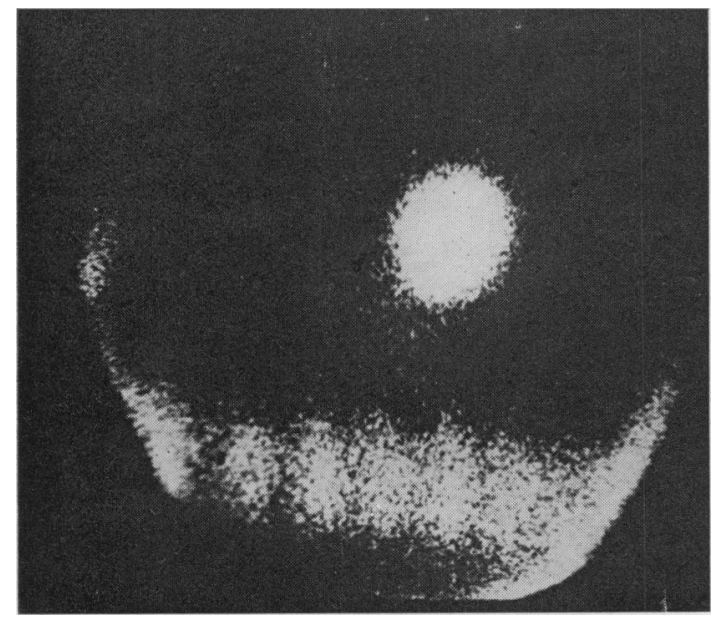

FIG. 2.-Spleen scan using $99 \mathrm{~m}$ Tc-labelled red cells, left lateral view. Scan shows spine and accessory spleen.

A similar scan using ${ }^{99 \mathrm{~m}} \mathrm{Tc}$-labelled platelets showed the accessory spleen with a large uptake in the liver, a little in the lungs, and also in the bone marrow.

At laparotomy on 24 August 1973 a splenunculus about the size of a golf ball was found in the transverse mesocolon close to the pancreas. It was removed. No other accessory splenic tissue was found despite a meticulous search. Postoperatively the maximum platelet count was $57000 / \mathrm{mm}^{3}$. Immunosuppressive therapy was stopped and prednisolone reduced to $5 \mathrm{mg}$ twice a day. Platelet counts over the period September 1973 to February 1975 were around $30000 / \mathrm{mm}^{3}$ with occasional counts up to $100000 / \mathrm{mm}^{3}$. A further 4month course of cyclophosphamide $100 \mathrm{mg}$ /day begun in October 1973 again had no significant effect on the platelet count. When last seen the patient was much improved, with few epistaxes. These were further ameliorated by cryosurgery to the nasal septum.

\section{Discussion}

This case illustrates the role of splenunculi in relapse of ITP after splenectomy. The recurrence rate after first operation has been reported as $14 \%$ (Giffin and Holloway, 1925), 17\% (Vaughan, 1937), and $15 \%$ (Watson-Williams, Macpherson, and Davidson, 1958). Watson and Moir (1941) noted that these recurrence rates were similar to the disdiscovery rate of splenunculi in routine necropsies. There are several well-documented reports of patients with ITP relapsing after splenectomy in whom splenunculi were found at necropsy. Morrison, Lederer, and Fradkin's (1928) case led others to look for splenunculi in life using Thorotrast and second operations. Rosenthal et al. (1951) reported 2 cases of splenunculi demonstrated by Thorotrast. Evans et al. (1953) and Brooks, O'Shea, and Pryor (1969) have included in each of their series a case in which the removal of an accessory spleen probably produced a remission.

The concept of accessory spleens causing relapse in ITP is an attractive one, especially in view of the known association between recurrence of hereditary spherocytosis and presence of splenunculi. However, the whole question must remain open. The reliable demonstration of accessory spleens by modern scanning techniques should now facilitate surgery and allow a review of a large number of relapsed cases to assess the significance of splenunculi in this condition.

\section{Summary}

In the case of a boy with relapsed thrombocytopenic purpura removal of a splenunculus, shown by radioisotope scanning, resulted in a partial remission. The significance of the association of relapse in ITP and the presence of splenunculi remains unknown: investigation of similar cases would clarify the matter.

We thank Professor D. J. Weatherall for support and encouragement. We also thank Mr. A. Cushieri for details of the case and Dr. T. M. D. Gimlette for allowing us to reproduce the spleen scans.

\section{REFERENCES}

Atkins, H. L., Eckelman, W. C., Hauser, W., Klopper, J. F., and Richards, P. (1972). Splenic sequestration of 99mTc-labeled red blood cells. Fournal of Nuclear Medicine, 13, 811. 
Brooks, P. L., O'Shea, M. J., and Pryor, J. P. (1969). Splenectomy in the treatment of I.T.P. British Fournal of Surgery, 56, 861.

Evans, T. S., Spinner, S., Piccolo, P., Swirsky, M., White, R., and Kieswetter, W. (1953). Recurrent hypersplenism due to accessory spleen. Acta Haematologica 10, 350.

Finkelstein, H. (1921). Ưber purpuraerkranburgen im Kindesalter. Fahreskurse für Arztliche Fortbildung, 12, 3.

Giffin, H. Z., and Holloway, J. K. (1925). A review of 28 cases of purpura haemorrhagica in which splenectomy was performed. American fournal of the Medical Sciences, 170, 186.

Macpherson, A. I. S. and Richmond, J. (1975). Planned splenectomy in treatment of idiopathic thrombocytopenic purpura. British Medical fournal, 1, 64 .

Morrison, M., Lederer, M., and Fradkin, W. Z. (1928). Accessory spleens-their significance in I.T.P. American fournal of the Medical Sciences, 176, 672.

Rosenthal, N. Vogel, P., Lee, S., and Lipsay J. J. (1951). The role of the accessory spleen in the post-splenectomy recurrent purpura hamorrhagica. Fournal of the Mount Sinai Hospital, 17, 1008.

Vaughan, J. M. (1937). Treatment of thrombocytopenic purpura. British Medical fournal, 2, 842.

Watson, C. J., and Moir, W. W. Jr. (1941). Recurrence of thrombocytopenic purpura after spelenctomy in cases with accessory spleen. New International Clinician, 4, 221.

Watson-Williams, E. J., Macpherson, A. I. S., and Davidson, S. (1958). The treatment of idiopathic thrombocytopenic purpura. Lancet, 2, 221.

I. M. HANN ${ }^{\star}$ and J. S. WAINSCOAT

University Department of Haematology, Liverpool Royal Infirmary, Liverpool.

^Correspondence to Dr. I. M. Hann, Alder Hey Children's Hospital, Liverpool L12 $2 \mathrm{AP}$.

\section{Benign rectal ulceration of unknown origin}

\section{An unusual cause of rectal bleeding}

Rectal bleeding in children is rarely of serious significance and the most common identifiable causes are superficial anal fissures associated with constipation and benign polyps of the large bowel. Rarer causes of fresh rectal haemorrhage in the young include peptic ulceration of a Meckel diverticulum, intestinal duplication, haemangiomata, and ulcerative colitis. In some patients the origin of the bleeding is never identified and it ceases spontaneously (Gross, 1953). This report describes an unusual cause of repeated rectal bleeding in an infant aged 18 months.

\section{Case report}

The patient, the second male child of a Negro Jamaican father and a white mother, presented in August 1973 at 18 months of age with a 6-day history of crying before defaecation and bleeding per rectum. There was no previous history of serious illness or of constipa- tion. Nothing abnormal was found on clinical examination. Haemoglobin was $10.8 \mathrm{~g} / \mathrm{dl}$ and the blood film hypochromic. Sickle test was negative and stool examination normal. Examination under anaesthetic and sigmoidoscopy showed no evidence of anal fissure or rectal polyp but a small area of ulceration was noted $9 \mathrm{~cm}$ from the anal margin. The infant was discharged home but returned after two days with further bleeding. Bleeding and clotting tests were normal and WR was negative. Barium enema examination was also normal.

Rectal bleeding, with and without defaecation, became more frequent in the following weeks and, in October 1973, a limited laparotomy was performed which excluded a Meckel diverticulum as the cause. Rectal biopsy in March 1974 showed normal mucosa adjacent to an area of ulceration and submucosal fibrosis, but there were no specific histological features. The frequency of bleeding increased in spite of treatment with sulphasalazine and rectal steroids. Repeat biopsies in June (Fig. 1) and September 1974 showed increasing submucosal fibrosis. A barium enema in September showed widening of the postrectal space consistent with inflammatory disease of the rectum. An anterior resection of the upper half of the rectum was performed in September 1974 (Fig. 1). In August 1975 the child had had no further symptoms and sigmoidoscopy showed no recurrence of the ulceration in the remaining portion of the rectum or in the colon.

Macroscopic appearance of resected specimen (Fig. 1). The fixed specimen was $6.5 \mathrm{~cm}$ in length and $6 \mathrm{~cm}$ wide. There was a deep ulcer $2 \mathrm{~cm}$ in diameter extending to within $0.5 \mathrm{~cm}$ of the distal end. Super-

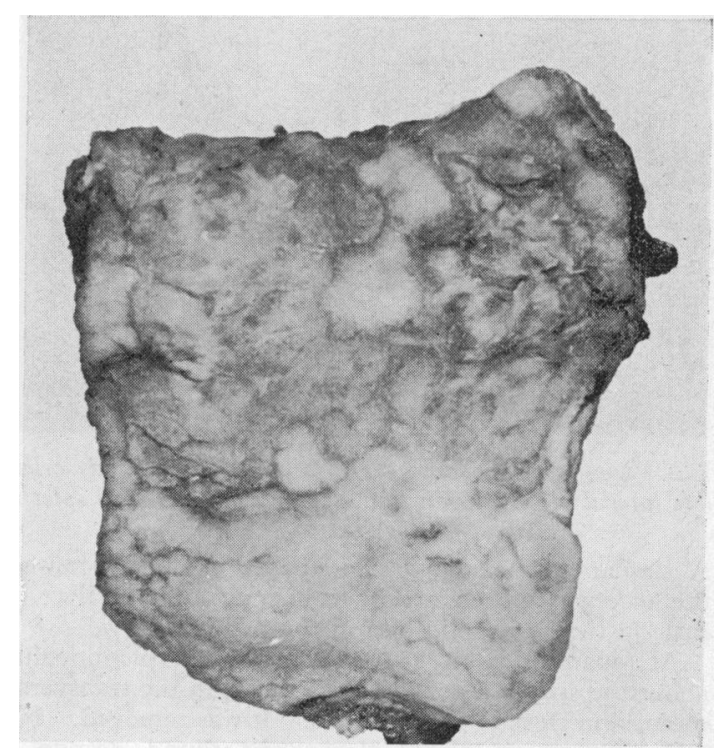

FIG. 1.-Resected specimen after fixation showing extensive ulceration with islands of mucosa. Distal cut end is at top. 